\title{
Selected Papers from 7th International Forum on Teacher Education - IFTE 2021: "Teacher Education: New Challenges and Goals"
}

\author{
Muhammet Usak $^{1^{*}}$, Alfiya R. Masalimova ${ }^{1}$ \\ ${ }^{1}$ Kazan Federal University, Kazan, Tatarstan Republic, RUSSIA
}

\begin{abstract}
IFTE Forum was launched in 2015 to create and promote mechanisms for collaboration between Russian and foreign scholars in the field of teacher education. In its seventh year, it has become one of the world's largest scientific platforms focusing on issues surrounding teacher education.

First IFTE Forum was attended by 165 participants. 101 of these participants gave oral presentations and plenary session included 8 reports. Due to the COVID19 pandemic that affected the world, the Forum was held virtually in 2020. Keynote lectures, synchronous paper sessions, symposia, round tables, workshops, and SIG meetings were held on the Microsoft Teams corporate platform. Thus, in the context of the COVID19 pandemic, IFTE-2020 became one of the world's largest virtual research platforms in the field of teacher education. This year, $7^{\text {th }}$ International Forum on Teacher Education - IFTE was organized with main topic "Teacher Education: New Challenges and Goals". More than 1,500 practitioners from 39 countries and 208 universities attended the conference.
\end{abstract}

The Forum was organized in a mixed format involving three separate formats:

1) Hybrid format involved two forums simultaneously, both online and face-to-face. For those participants who could not visit the forum and present their papers in auditoriums, online forum is broadcasted via Microsoft Teams.

2) Face-to-face format only took place in auditoriums with participants who have come to the forum.

3) Remote format was used for those participants who will only participate in an online format using Microsoft Teams.

Out of 480 papers, 121 papers were selected for blind review to be published in EJMSTE. After additional review, 12 papers were selected for publication in this special issue. These 12 articles are related to online learning, mathematics education, digital technology, and science teacher education. Recent research shows that the outbreak of COVID-19 pandemic disrupted traditional forms of teaching and learning that is centered on in-class instruction (Colomo Magaña et al., 2021; Eleftheriadi et al., 2021; Maphosa, 2021; Murphy et al., 2020; Rogayan et al., 2021; Tabassum et al., 2021; Tesfamicael \& Ayalew, 2021; Tseng \& Chen, 2020). Student perceptions, preferences, and emotional responses have shifted with the transition to a virtual learning environment. From the evaluation of the selected papers from the IFTE-2021 Forum, we also observe that after COVID-19 outbreak, online learning and social media gained importance in STEM Education. We appreciate the scholarly excellence of the articles accepted for publication and congratulate the authors.

Special issue starts with the article by Gafarov et al. entitled "A Complex Neural Network Model for Predicting a Personal Success based on their Activity in Social Networks" (Gafarov et al., 2021), which presents a comprehensive model of success based on artificial neural networks and an analysis of qualitative and quantitative data. This tool is proposed to be used by psychologists in educational, professional, and other areas in the formation of trajectories of harmonious person's development. Active research is stated to be underway to determine psychological characteristics based on publicly available data. Such studies develop the direction of "Psychology of social networks". As a result, classic methods of information processing become inefficient.

“Adult Learners' Responses to Online Learning: A Qualitative Analysis Grounded in Self-determination Theory" by Salikhova et al. (2021) identified elements of online courses that correspond with and facilitate the satisfaction of each of the three basic psychological needs: autonomy, competence, and relatedness. At a time when educators in many countries are adopting digital technology in their classrooms, whether by choice or mandate, the question of what the experience of online learning is like for students remains open and of vital interest. 
"Formation of Computational Thinking Skills Using Computer Games in Teaching Mathematics" by Soboleva et al. (2021) aims to resolve the contradiction between requirements of the modern economy for specialists' high level of computational thinking and an insufficiently developed methodological base for training graduates that meets these requirements. The research is relevant as educational computer games are included in students' mathematical activity and form additional opportunities to improve the quality of teaching mathematics in a digital school, to support the formation of the demanded professional competence computational thinking. The purpose of this research is stated as "to study the features of using gamification technologies in teaching mathematics to form the skills and abilities that make up the essence of computational thinking".

"Methods of Using Cases from the Life of Outstanding Mathematicians in the Training of Future Teacher" by Pavlova et al. (2021) presents a system of work, including getting to know the cases from the life of scientists in the framework of training sessions, setting practice-oriented tasks for organizing independent work of students and organizing extracurricular educational activities in the form of group projects, that may contribute to the formation of the future teacher's readiness to use the educational potential of cases from the life of scientists in educational work. Biographies of outstanding mathematicians were analyzed and cases related to the manifestation of their qualities in various life situations were identified.

"Using "Deep Learning School" with Digital Technologies in Science and Technology" by Kurbanova and Yarovikov (2021) introduces a digital technology of education and career guidance that was created within the open free resource "Deep Learning School" (DLS) with the aim of recruiting and education of talented youth in the field of IT research and development.

"Transformation of the Assessment of the Quality of Educational Activities and Training of Future Science Teachers in the Context of the Pandemic" by Khodyreva et al. (2021) proposes the concept of transformation of the assessment of the quality of educational activities and the training of future science teachers, the main ideas of which are the objectivity of the assessment; its complex nature; the technological nature of the assessment procedures; their openness; the unity of normative and "non-normative" criteria.

"Using Interactive Platform "Round" to Organize Online Leisure Activities for Children During the Pandemic" by Kayumova et al. (2021) aims to analyze modern interactive platforms, identify their potential in organizing leisure activities, and determine the conditions for using the platform "Round" for leisure activities of primary school children. Quarantine restrictions and regulations related to COVID-19 revealed the problems of organizing both communication and leisure activities online. Organized leisure activities are recognized as the main means for the socialization of children. As a result of the study, the possibilities of introducing the platform "Round" for organizing leisure activities for children with different developmental levels and/or with difficult socio-economic conditions, who do not have the opportunity to receive additional education services, were identified.

"Digital Literacy and its Relevance to Comparative Education Researchers: Outcomes of SciVal Analytics" by Chigisheva et al. (2021) states the lack of serious scientific reflection on the currently witnessed "shock digitisation" of science, complicated with growing digital illiteracy of researchers. The article concludes that the field of comparative education research requires future profound rethinking of assumptions and agenda priorities in several aspects including general qualification requirements for modern comparative education researcher and comparative research procedures, functional and digital literacy of comparativists, and changes in their research career potentials and prospects.

"STEM and STEAM Education in Russian Education: Conceptual Framework" by Shukshina et al. (2021) examines the STEM approach as one of the revolutionary tools for transforming education. The paper discloses the content of the concept of "STEAMeducation", substantiates its importance and prerequisites for its appearance. The authors elucidate a comparative analytical review of trends and prospects for the development of STEAM education in the Russian Federation. The authors also want to touch upon a comprehensive theoretical and methodological study conducted on the declared problem to identify the problem of the formation and development of the STEAM approach in the education system in the Russian Federation at all levels: general education, vocational education, and additional education.

"Descriptors Derived From Feedback on Teaching Mathematics in School" by Ibragimov and Kalimullina (2021) aim to identify the mechanism of bilateral feedback on Mathematics homework and to determine its impact on the success of schoolchildren learning. The following were used as the main research methods: the study and generalization of pedagogical experience which helped to consider possible ways of providing feedback on homework in Mathematics; the analysis of student artefacts with subsequent statistical processing.

"Key Problems of Complex Topics in Mathematics as the Basis of Teaching Methods in the Conditions of Self-Education" by Zelenina et al. (2021) states that ensuring a high quality of teaching mathematics to 
students is inextricably linked with teaching how to solve creative mathematical problems that traditionally include tasks of high educational, developmental and diagnostic value. The purpose of this research is to develop and describe a teaching methodology for solving problems with parameters based on the allocation of basic (key) problems. The authors have developed a methodology for constructing a system of tasks based on systematizing the theoretical and task material, highlighting students' basic knowledge and skills, describing the intra- and inter-subject connections of the topic "Equation of a circle in tasks with parameters".

In the final article entitled "Competitive Teacher for Higher Education: Risk-Based Models of its Development" by Salakhova et al. (2021), authors aim at solving the problem of determining the structure, content and conditions for the implementation of pedagogical support to enhance the competitiveness of a higher education teacher for a VUCA world, as well as ensuring the effective formation of teachers' noxological competences for a VUCA world in the information and educational environment of a higher education institution.

\section{REFERENCES}

Chigisheva, O., Soltovets, E., Dmitrova, A., Akhtyan, A. G., Litvinova, S. N., \& Chelysheva, Y. V. (2021). Digital literacy and its relevance to comparative education researchers: Outcomes of SciVal analytics. Eurasia Journal of Mathematics, Science and Technology Education, 17(10), em2017. https:/ / doi.org/10.29333/ ejmste/11183

Colomo Magaña, E., Cívico Ariza, A., Ruiz Palmero, J., \& Sánchez Rivas, E. (2021). Problematic use of ICTs in trainee teachers during COVID-19: A sexbased analysis. Contemporary Educational Technology, 13(4), ep314. https://doi.org/10.30935 /cedtech/10988

Eleftheriadi, A., Lavidas, K., \& Komis, V. (2021). Teaching mathematics in early childhood education with ICT: The views of two contrasting teachers' groups. Journal of Digital Educational Technology, 1(1), ep2103. https:// doi.org/10.21601 /jdet/11117

Gafarov, F. M., Nikolaev, K. S., Ustin, P. N., Berdnikov, A. A., Zakharova, V. L., \& Reznichenko, S. A. (2021). A complex neural network model for predicting a personal success based on their activity in social networks. Eurasia Journal of Mathematics, Science and Technology Education, 17(10), em2010. https:/ / doi.org/10.29333/ ejmste/ 11175

Ibragimov, G. I., \& Kalimullina, A. A. (2021). Descriptors derived from feedback on teaching mathematics in school. Eurasia Journal of
Mathematics, Science and Technology Education, 17(10), em2019. https:/ / doi.org/10.29333/ejmste/ 11185

Kayumova, L. R., Gainullina, L. N., Akhmadieva, R. S., Matvienko, V. V., \& Kabakhidze, E. L. (2021). Using interactive platform "Round" to organize online leisure activities for children during the pandemic. Eurasia Journal of Mathematics, Science and Technology Education, 17(10), em2016. https://doi.org/10.29333/ejmste/11182

Khodyreva, E. A., Kalimullin, A. M., Zheltukhina, M. R., \& Chizh, N. V. (2021). Transformation of the assessment of the quality of educational activities and training of future science teachers in the context of the pandemic. Eurasia Journal of Mathematics, Science and Technology Education, 17(10), em2015. https:/ / doi.org/10.29333/ejmste/ 11180

Kurbanova, A. T., \& Yarovikov, Y. N. (2021). Using "Deep Learning School" with digital technologies in science and technology. Eurasia Journal of Mathematics, Science and Technology Education, 17(10), em2014. https:/ / doi.org/10.29333/ ejmste/ 11179

Maphosa, V. (2021). Teachers' perspectives on remotebased teaching and learning in the COVID-19 era: Rethinking technology availability and suitability in Zimbabwe. European Journal of Interactive Multimedia and Education, 2(1), e02105. https:/ / doi.org/10.30935/ejimed/9684

Murphy, L., Eduljee, N. B., \& Croteau, K. (2020). College student transition to synchronous virtual classes during the COVID-19 pandemic in Northeastern United States. Pedagogical Research, 5(4), em0078. https://doi.org/10.29333/pr/8485

Pavlova, O. A., Zaripova, Z. F., Zagitova, L. R., \& Zakirova, V. G. (2021). Methods of using cases from the life of outstanding mathematicians in the training of future teacher. Eurasia Journal of Mathematics, Science and Technology Education, 17(10), em2013. https:/ / doi.org/10.29333/ejmste/ 11178

Rogayan Jr., D. V., \& Dantic, M. J. P. (2021). Backliners: Roles of science educators in the post-COVID milieu. Aquademia, 5(2), ep21010. https:/ / doi.org/10.21601/aquademia/11053

Salakhova, V. B., Masalimova, A. R., Belyakova, N. V., Morozova, N. S., Osipova, N. V., \& Prokopyev, A. I. (2021). Competitive teacher for higher education: Risk-based models of its development. Eurasia Journal of Mathematics, Science and Technology Education, 17(10), em2021. https://doi.org/ 10.29333 / ejmste/11187

Salikhova, N. R., Lynch, M. F., \& Salikhova, A. B. (2021). Adult learners' responses to online 
learning: A qualitative analysis grounded in selfdetermination theory. Eurasia Journal of Mathematics, Science and Technology Education, 17(10), em2011. https://doi.org/10.29333/ejmste/ 11176

Shukshina, L. V., Gegel, L. A., Erofeeva, M. A., Levina, I. D., Chugaeva, U. Y., \& Nikitin, O. D. (2021). STEM and STEAM education in Russian education: Conceptual framework. Eurasia Journal of Mathematics, Science and Technology Education, 17(10), em2018. https://doi.org/10.29333/ejmste/ 11184

Soboleva, E. V., Sabirova, E. G., Babieva, N. S., Sergeeva, M. G., \& Torkunova, J. V. (2021). Formation of computational thinking skills using computer games in teaching mathematics. Eurasia Journal of Mathematics, Science and Technology Education, 17(10), em2012. https://doi.org/ 10.29333/ ejmste/11177

Tabassum, M., Mannan, S. E., Parvej, M. I., \& Ahmed, F. (2021). Online education during COVID-19 in Bangladesh: University teachers' perspective.
Aquademia, 5(1), ep21005. https://doi.org/ 10.21601/aquademia/9611

Tesfamicael, S. A., \& Ayalew, Y. (2021). Mathematics education in Ethiopia in the era of COVID-19: Boosting equitable access for all learners via opportunity to learning. Contemporary Mathematics and Science Education, 2(1), ep21005. https:// doi.org/10.30935/conmaths/9680

Tseng, C.-J., \& Chen, T.-C. (2020). Impact of web-based teaching on the learning performance of education and training in the service industry during COVID-19. Contemporary Educational Technology, 12(2), ep277. https://doi.org/10.30935/cedtech/ 8581

Zelenina, N. A., Telegina, N. V., Pronchev, G. B., Yagudina, R. I., Galimov, F. M., \& Slepneva, E. V. (2021). Key problems of complex topics in mathematics as the basis of teaching methods in the conditions of self-education. Eurasia Journal of Mathematics, Science and Technology Education, 17(10), em2020. https://doi.org/10.29333/ejmste/ 11186

\section{http://www.ejmste.com}

